\title{
Will-skill-tool (WST) model of technology integration in teaching science and mathematics in the Philippines
}

\author{
Randolf S. Sasota ${ }^{1} \cdot$ Ruby R. Cristobal $^{1} \cdot$ Imelda S. Sario $^{1} \cdot$ Josette T. Biyo $^{1}$ • \\ Joselito C. Magadia ${ }^{2}$
}

Received: 29 October 2019 / Revised: 15 December 2020 / Accepted: 10 February 2021 / Published online: 9 March 2021

(C) The Author(s) 2021

\begin{abstract}
The proliferation of information and communication technologies (ICT) in the twenty-first century has challenged the status quo of educational setting and led to a paradigm shift in teaching and learning processes. ICT use and integration in teaching then, becomes an essential component of pedagogical processes to have an effective teacher-student interaction and to optimize learning. While past studies have already established evidence that attitude toward ICT (will), ICT skills (skill), and availability of ICT resources (tool) elements are indeed important contributors to the integration of ICT in teaching, little attention has been paid yet to differences in these elements and in this model of ICT integration between subject areas of science and mathematics. Thus, this study aims to examine the significant differences in these factors between science and mathematics (S\&M) teaching guided by the Will-Skill-Tool (WST) model developed by Christensen and Knezek (2001, 2008). Using independent samples $t$ test and multiple linear regression, results show that science teachers had higher scores in will, skill, tool, and ICT integration indices compared to mathematics teachers. Findings also revealed that WST model of ICT integration differs between science and mathematics areas, particularly in terms of which among the factors had the strongest influence on ICT integration. The study recommends distinct approaches in providing capacity training development on ICT integration for teachers considering the context of subject specific area.
\end{abstract}

Keywords Technology integration · Will-skill-tool model $\cdot$ ICT skills $\cdot$ Attitude toward ICT $\cdot$ Availability of ICT tools $\cdot$ Science and mathematics teaching

Randolf S. Sasota

randolf.sasota@gmail.com

1 Department of Science and Technology - Science Education Institute (DOST-SEI), Levels 1 \& 2, Phil. Science Heritage Bldg., Gen. Santos Ave., Bicutan, Taguig, Republic of the Philippines

2 School of Statistics, University of the Philippines - Diliman, Diliman, Quezon City, Philippines 


\section{Introduction}

The proliferation of digital technology, particularly information and communication technology (ICT), in the twenty-first century has challenged the status quo of educational setting and led to a paradigm shift in teaching and learning processes. ICT use and integration in teaching then becomes an essential component of pedagogical processes to have an effective teacher-student interaction and to optimize learning.

Several studies have contributed to understanding the factors predicting ICT use and integration in teaching (Agyei and Voogt, 2010; Aramide et al. 2015; BuabengAndoh, 2012; Farjon et al. 2019; Hew and Tan 2016; Peeraer and Van Petegem 2010; Vannatta and Fordham 2004). Findings of previous studies can be synthesized using the Will-Skill-Tool (WST) model developed by Christensen and Knezek (2001, 2008). Significant factors of ICT integration identified by previous studies can be categorized under Will (which Christensen and Knezek referred to as computer attitude of the teacher), Skill (which pertains to technology competence), and Tools (which refers to access to technology tools). Previous studies used different variable terms, yet each can fall into one of these three key elements of WST model. Included in the Will category are: lack of anxiety (Agyei and Voogt 2010); lack of teacher confidence (Buabeng-Andoh 2012); attitude and beliefs toward technology (Farjon et al. 2019), level of IT curricular expectations; teachers' beliefs in studentcentered teaching-learning (Hew and Tan 2016); computer confidence (Peeraer and Van Petegem 2010); and openness to change (Vannatta and Fordham 2004). Technology competency (Agyei and Voogt 2010), educational qualification, teaching experience, ICT use experience (Aramide et al. 2015), lack of teacher ICT skills, lack of pedagogical teaching (Buabeng-Andoh 2012), competency of technology use (Farjon et al. 2019), ICT skills (Peeraer and Van Petegem 2010), and amount of technology training (Vannatta and Fordham 2004) are the variables identified as significant factors of ICT integration that can be categorized under Skill element. Classified under Tool category are ICT accessibility, location of ICT resources (Aramide et al. 2015), lack of suitable educational software, limited access to ICT (BuabenAndoh 2012), access to technology (Farjon et al. 2019), and computers per student, and IT resources (Hew and Tan 2016). Previous studies have established that will (computer attitude), skill (technology competency), and tool (access to technology tools) are all essential ingredients for a teacher to effectively integrate ICT in teaching.

While past studies have already established evidence that will, skill, tool elements are indeed important contributors to the integration of ICT in teaching, little attention has been paid yet to differences in these elements and in this model of ICT integration between subject areas of science and mathematics. As suggested by Nelson et al. (2019) and Foulger et al. (2015), studies in technology integration that consider subject culture should be done to give information on how to successfully integrate ICT into teaching, which is contextually subject specific. Thus, this study explores this gap by examining significant differences in the will, skill, tool, and ICT integration between science and mathematics (S\&M) teaching. 
The study focused on using ICT in teaching science and mathematics in the classroom rather than other subjects because ICT is evidently becoming a necessary tool to enhance the learning of these subjects. A study that compared the use of ICT in various educational domains showed that Science, Technology, Engineering, and Mathematics (STEM) teachers recognize the benefits of using ICT in teaching more than those teaching humanities and social sciences and that they "perceived themselves as more competent in ICT use compared to other two groups" (Zubkovic et al. 2017).

ICT enables collaboration among teachers, among students, and between students and experts in research, as well as in designing and building products and methodologies. It offers tools for STEM teachers to introduce new and abstract concepts, demonstrate processes that are difficult to set up in a laboratory or classroom, motivate students, and assess their performance. Beyond the science classroom, ICT can be used to collect and analyze data during field experiments, a regular component of science and research learning which is not required nor practiced in other subjects. By focusing the study in science and mathematics, the specific benefits of using ICT for teaching the subjects can be assessed and maximized by understanding the factors that influence how the teacher is limiting or advancing its use.

Findings of this research may contribute to the context validation of WST model, particularly in the Philippines and in teaching science and mathematics. Results on significant differences in the will, skill, tool, and ICT integration and in the ICT integration model per se may also help in conceptualizing programmatic pedagogical teacher trainings that are contextualized to particular subject area.

\section{Literature review}

\section{A conceptual framework of the study: the will-skill-tool model}

This study adapted the Will-Skill-Tool (WST) model developed by Christensen and Knezek (2001, 2008). According to the model, the Will, Skill, and Tool constructs independently predict the integration of technology in the classroom. They are hypothesized to be essential elements for a successful integration of technology into teaching. In other words, integration of ICT in teaching is a function of internal factors (i.e., will and skill) and external factor (i.e., tool). High integration is likely among those who are willing to use (will), equipped with ICT skills (skill), and provided with equipment and facility (tool). Though tool can be an antecedent or intervening variable of will and skill of teachers (Inan and Lowther 2010; Vongkulluksn et al. 2018), this study focused only on the original model that will, skill, and tool independently influence integration of ICT in teaching. Will refers to the affective inclination toward the use of technology in teaching. Skill is conceptually defined as the ability to perform ICT-related tasks. Tool pertains to the availability of ICT resources. ICT integration in teaching is conceptually defined as the extent of incorporation of ICT in teaching and learning process.

While there are other existing models in technology integration (e.g., Shaw et al. 2018; Taimalu and Luik 2019; Teo and Bahçekapili 2012; Vongkulluksn 
et al. 2018) WST model was chosen for this study because of its parsimonious, yet multi-dimensional approach in explaining technology integration in teaching. Compared to the Technology Integration Model (TIM) of Shaw et al. (2018), the extended Technology Acceptance Model (TAM) of Teo and Bahçekapili (2012), and Taimalu and Luik's (2019) Model (TLM) that all consisted of more than three constructs, the WST model, developed specifically for teachers, consisted of only three core variables. However, past studies using WST model recorded high total variability explained, ranging from 60 to 96\% (Farjon et al. 2019; Morales 2006). Moreover, TIM, TAM, and TLM focused primarily on internal factors such as cost-benefit decision, situational context, knowledge, self-efficacy, beliefs, attitude, and perceptions of usefulness and ease of use. Conversely, the WST model encompasses both internal (will and skill) and external (tool) factors. This model has become popular through its inclusion in the International Handbook of Information Technology in Primary and Secondary Education (Voogt and Knezek 2008).

The study considered similar use of the WST model by various researches done in other countries deemed relevant in the Philippine context. However, the instruments used to measure will, skill, tool, and integration are different. Despite of non-use of conventional measures of WST, the reliability tests and research findings revealed high Cronbach's alpha and significant results.

Demographic attributes (control variables) of teachers, their influence on attitude toward use of computers (will), their competence in ICT (skill), as well as their access to ICT resources were used to predict how teachers are able to integrate ICT in teaching science and mathematics in the classroom The conceptual framework shows the direct effect of control variables on will and skill. The Will, Skill, and Tool are hypothesized to predict ICT integration in teaching science and mathematics (See Fig. 1).

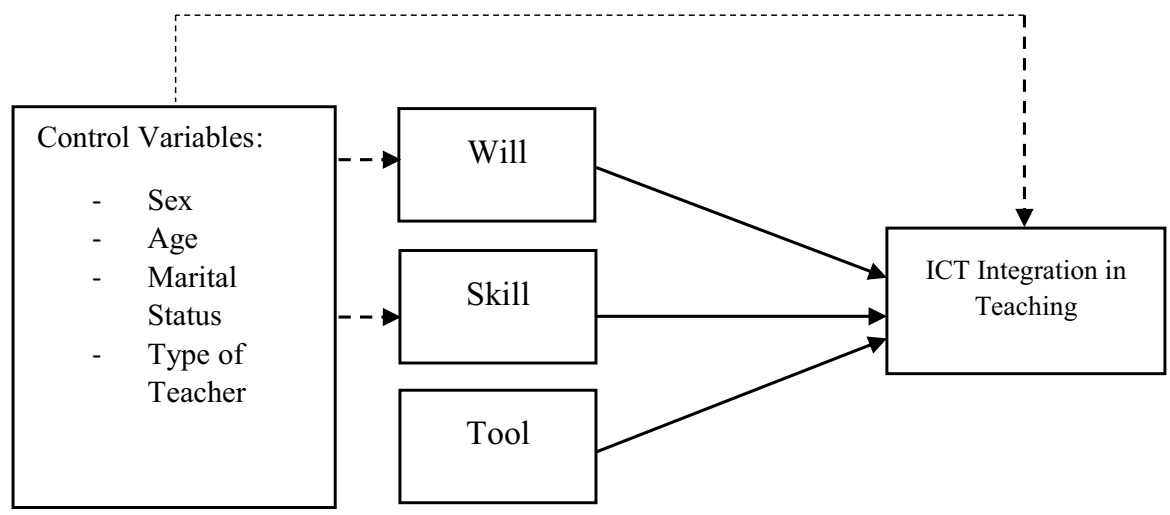

Fig. 1 Conceptual framework in analyzing the WST model of ICT integration in S\&M teaching 


\section{Demographic variables and ICT integration in teaching}

Past studies showed different results on the relationship between age and ICT integration in teaching. Some studies revealed significant relationship between these variables (Inan and Lowther 2010; Lau and Sim 2008; O'Bannon and Thomas 2014; Scherer et al. 2015). Most studies found that age negatively influences ICT integration (e.g., Inan and Lowther 2010; O'Bannon and Thomas 2014; Scherer et al. 2015). For example, Scherer et al. (2015) revealed that older teachers tended to treat ICT use for other purposes as less useful, and possible problems and obstacles for teaching and learning as more present than younger teachers. However, the study by Lau and Sim (2008) found that older teachers were more likely to use computer technology than younger teachers. Conversely, there were recent studies also that showed no significant relationship between age and ICT integration in teaching (Aramide et al. 2015; Farjon et al. 2019; Gil-Flores et al. 2017; Ifinedo et al. 2020; Siddiq et al. 2016).

Results of past studies on the difference in ICT integration into teaching between male and female teachers were also inconsistent across countries (Gebhardt et al. 2019) and past studies (e.g., Aramide et al. 2015; Oosterwegel et al. 2004). Some studies reported significant sex effects on ICT use in education across different teacher samples and cohorts (Gebhardt et al. 2019; Oosterwegel et al. 2004; Sink et al. 2009; Tondeur et al. 2008; Volman and van Eck 2001). For instance, Gebhardt et al. (2019) analyzed the sex differences in ICT use across 12 countries using the International Computer and Information Literacy Study (ICILS) 2013 of the International Association for the Evaluation of Educational Achievement (IEA). Differences were significant in eight of the 12 countries. There was a greater percentage of female teachers than male teachers reported using ICT in the classroom in every country. However, other recent studies found no significant relationship between sex and ICT integration in teaching (Aramide et al. 2015; Farjon et al. 2019; Gil-Flores et al. 2017; Ifinedo et al. 2020; Siddiq et al. 2016).

With the inconsistent findings from past studies on differences in ICT integration in teaching across age and sex, this current study may contribute to understanding differences in the context of teaching science and mathematics in the Philippines. The authors did not find related studies that dealt with differences in ICT integration in teaching between married and single teachers. However, the variable was still included in the study as it is hypothesized to be a significant factor that influence ICT integration in teaching in the Philippine setting, at least.

\section{Past studies that used WST model in ICT integration in teaching}

Knezek et al. (2003) found that 70-84\% of teachers' level of Technology Integration could be predicted by Will, Skill, and Tool model, using data collected from 1999 to 2001. Their study also revealed that $8-12 \%$ per year of first and second grade technology intensive reading achievement can be attributed to the level of classroom Technology Integration. Morales et al. (2005) studied 10 teacher school district samples from 2001 to 2005 and found Will, Skill, and Tool accounted for 
64-83\% of the variance in Technology Integration proficiency for practicing teachers. Morales (2006) conducted a comprehensive transnational study of the model using refined measures for seven samples of teachers from Mexico and the USA and concluded $90-96 \%$ of classroom Technology Integration could be attributed to Will, Skill, and Tool measures for these teachers. Skill was the strongest predictor of technology integration in the USA, whereas Tool was the strongest predictor in Mexico. The study of Agyei and Voogt (2010) among prospective and mathematics teachers in Ghana revealed $43 \%$ of the total variance in ICT integration in teaching can be explained by WST model. The strongest predictor was skill, followed by will measured by lack of computer anxiety. Petko (2012) used the WST model with self-selected measure to examine the effect of constructivist teaching style on the use of digital media in Swiss classrooms. Five factors accounted for a total of $60 \%$ of the variance in the intensity of use of information and communication technologies. Among these were teacher confidence in their competence, access to technology, teacher belief in the power of technology to improve learning and frequency of constructivist forms of teaching and learning (Petko, 2012). Knezek and Christensen (2016) added pedagogy construct in the original model and found that $34 \%$ of teacher level of technology integration can be attributed to Will, Skill, Tool, and Pedagogy (WSTP) model. Recently, Farjon et al. (2019) extended the WST model by adding teaching experience. The WST model explained $60 \%$ of the variation in pre-service teachers' technology integration. Adding teaching experience to the model did not improve the prediction.

Though Farjon et al. (2019) considered selecting their respondents from different subject areas, the findings focused on the general analysis of the model but there was no differential analysis by subject-specific areas like other past studies cited above. This present study fills this gap of examining significant differences in the will, skill, tool, and integration of ICT into teaching, particularly between science and mathematics teaching.

\section{Recent studies on differences in ICT integration into teaching across subject areas}

Howard and Maton (2011) examined the different patterns of integration of information and communication technologies between Mathematics and English teachers using qualitative analysis approach. Using Legitimation Code Theory (LCT) analysis that examines the bases of achievement underlying social contexts as a means of understanding practice (Maton, 2010), they found that mathematics teachers were less likely to integrate ICT in teaching than English counterparts. ICT was not preferred by mathematics teachers when the focus of learning was on knowledge practices such as "drill and practice". Jang and Tsai (2012) studied significant differences in technology integration measured by technological pedagogical and content knowledge (TPACK) (Mishra and Koehler 2006) between elementary science and mathematics teachers. Using quantitative analysis (i.e., independent samples $\mathrm{t}$ tests), they found that elementary science teachers had higher technology integration compared to mathematics teachers. Sezer (2015) included more subject areas 
in examining differences in technology integration measured by TPACK and found that there were statistically significant differences between Mathematics and Turkish Literature; between Mathematics and Social Sciences; between Science and Technology and Turkish Literature; between Science \& Technology and Social Sciences; and between Turkish Literature and Social Sciences. More recent study of Nelson et al. (2019) among teacher educators using Structural Equation Modeling (SEM) found no direct influence of subject area on technology integration (TPACK). However, teacher educators who exclusively prepared teachers in English and Mathematics possessed lower TPACK than Science teacher educators and educational technology teacher educators. Nelson et al. (2019) argued that it is possible that mathematics as a subject requires specialized technologies (e.g., software) that are unique to that content area.

Based on the study of Nelson et al. (2019) that recommended that educational programs should use comprehensive approaches that give opportunities to teachers to see technology in relevant context, this present study addresses the gap of limited studies that analyzed ICT integration model by subject areas, particularly between science and mathematics.

Thus, the study sought to answer the following research questions:

1. How well do the will, skill, and tool predict the integration of ICT in teaching science and mathematics?

2. How do will, skill, tool, and ICT integration in teaching differ between science and mathematics teaching?

3. How does the WST model of ICT integration differ between science and mathematics teaching?

\section{Method}

\section{Respondents}

A total of 325 teachers (163 science teachers and 162 mathematics teachers) who were purposively sampled from 16 science, technology, and engineering (STE) implementing high schools participated in this study. The criteria for selecting the respondents were subject being taught and belonging to STE implementing high schools. Geographical spread of schools was considered in selecting the schools. Selected schools are located in three major areas of Luzon, Visayas, and Mindanao, particularly, four schools in the National Capital Region (NCR), and three schools each in other regions, namely, Regions 2, 5, 6, and 11. At least 10 science teachers and 10 mathematics teachers from each school were asked to participate in the study, except for one school from Region 2 with less than 10 science or mathematics teachers. There were more female teachers $(242,74.5 \%)$ than male teachers $(83$, $25.5 \%$ ). The average age of teachers was 40 ; the youngest was 25 while the oldest was 63 years. The average teaching experience was approximately 15 years, ranging from as low as 1 year to 40 years long. 


\section{Research instrument}

The questionnaire used in collecting data in this study was patterned after the instrument used by the Department of Education and Training Evaluation and Accountability Western Australia (2006) in its paper on teacher ICT skills of Western Australian government school teachers. The validity of the measures was established and discussed in their report. The questionnaire in this study had several sections. The first section of the questionnaire was used to collect data on demographic characteristics such as age, sex, marital status, and years of teaching experience. Following were sections about ICT resource and facilities, ICT knowledge and skills, access to ICT-related trainings, attitude toward ICT, personal and professional use of ICT, application of ICT in the classroom, assessing student outcomes using ICT, and obstacles in using ICT (See Appendix for the Survey Questionnaire). To establish the face and content validity of the measures, three (3) experts in the field were asked to investigate the set of items vis-àvis the constructs under study. They all agreed that measures were valid, at least at the face and content level. Then, the instrument was pilot-tested in a science high school from the National Capital Region to see appropriateness and clarity of terms used. Finally, the questionnaire was revised and finalized considering the suggestions and comments raised by teachers during the pilot testing. Factor analysis and reliability tests of the constructs conducted after gathering the data showed evidence of reliability and validity (i.e., construct).

\section{Variables}

The variables selected for this study correspond to items from the questionnaires completed by teachers. Some variables (i.e., attitude toward ICT, ICT skills, availability of ICT resources, and ICT integration) are indices created based on scale analyses that used several items contained in the questionnaire. Scale scores for these indices are estimates of latent traits constructed by adding the scores of corresponding items. Each set of items measuring a latent variable underwent confirmatory factor analysis and internal reliability test prior to index construction.

The dependent variable is ICT integration index constructed using 35 items from five questions on different aspects of integration:

- Q9. How often do you incorporate the following ICT-related tools in your teaching of science/mathematics (e.g., Tutorial/Exercise software);

- Q19. Please estimate how often you use ICT to achieve the listed personal/ professional objectives. (e.g., Create materials for students use such as handouts, tests);

- Q20. Please choose only one description that best describes your situation. In my current teaching, ICT is: (e.g., Having an extensive impact on what students learn and how they learn); 
- Q21. Please estimate how often you incorporate student use of ICT to achieve the following learning outcomes (e.g., Mastering skills just taught); and

- Q22. Please estimate how often you use the listed ICT activities when assessing student outcomes (e.g., Student assignments that incorporate a learning experience involving use of ICT application).

All items were measured on four-point scale, with different response categories: Q19, Q21, and Q22 items have response categories of 1 for "never", 2 for "at least once per term", 3 for "weekly", and 4 for "daily"; Q9 item has response categories of 1 for "never", 2 for "sometimes", 3 for "often", and 4 for "nearly always". Q20 item has response category of four description statement-each has corresponding score from 1 to 4 . The ICT integration index has high internal reliability test with Cronbach's alpha $(\alpha)$ of 0.94 .

The independent variables considered in this study includes two sets: (1) demographic characteristics of the teachers and (2) WST variables.

The first set includes demographic characteristics of the teachers: sex (male or female), age, marital status (single or otherwise), and type of teacher (science or mathematics teacher).

The second set of variables provides the WST variables. Under Will element is attitude toward ICT measured by 11 items from one question: Q18. Please indicate the extent to which you agree or disagree with each statement about ICT (e.g., Student use of ICT has the capacity to strongly support student-centered, inquiry-based learning). The 11 items were measured on a four-point scale, with response category of 1 for "strongly disagree", 2 for "disagree", 3 for "agree", and 4 "strongly agree". A high value of attitude toward ICT index indicates positive predisposition toward ICT use. Attitude toward ICT variable has a high Cronbach's alpha $(\alpha)$ of 0.94 indicating high internal consistency among the items.

On Skill element, ICT skills index was created using 83 items that determine the skills of teachers on computer tools, namely: computer file navigation; email; Internet; word processor; presentations; spreadsheets; and databases. Teachers were asked to indicate which skills teachers already have for each type of software (e.g., Q10. With Computer File Navigation like Windows Explorer I can: a. save files in a selected folder; $b$. create and name new folders; $c$. navigate into a network; $d$. copy, delete and rename files; e. select and navigate between drives and directories; $f$. use appropriate Help files; $g$. install software; $h$. recognize different file types; $i$. zip and unzip files; and $j$. do complex searches for files). ICT skills index has high internal consistency with Cronbach's alpha $(\alpha)$ of 0.98 .

Availability of ICT resources was a variable created for Tool element. It was measured using eight items that determine the availability of certain ICT resources such as desktops/laptops for teacher use, desktops/laptops for student use, school intranet, Internet, printer, digital cameras, digital projectors for student/teacher use in the classroom, and desktop computers for student/teacher use elsewhere at school (e.g., computer laboratory). Teachers were asked if each of the ICT resources was available in the school. Created variable on availability of ICT resources has relatively high internal reliability with Cronbach's alpha $(\alpha)$ of 0.83 . 


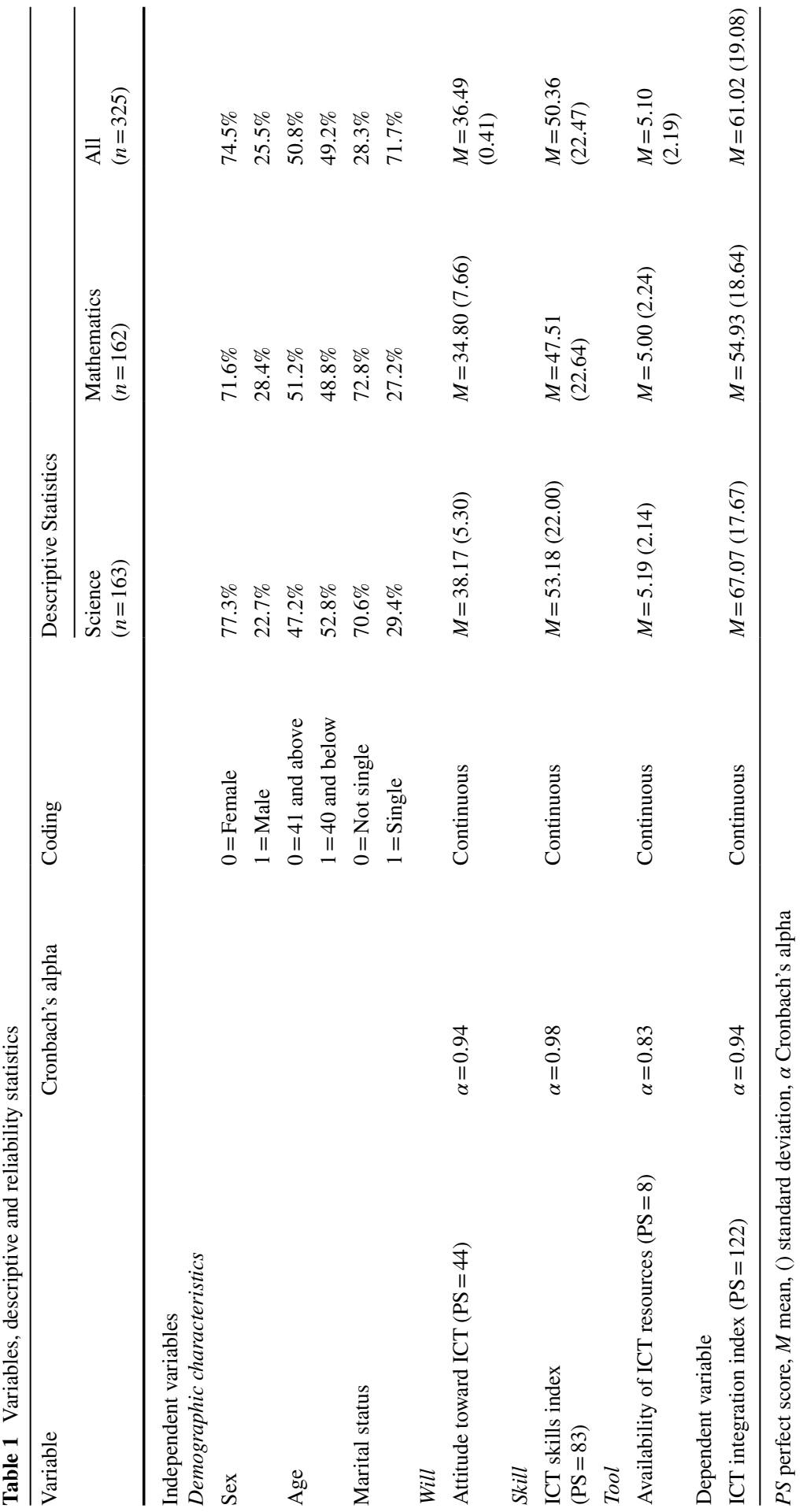


Table 1 presents a list of the variables considered in the study, including descriptive statistics. In the case of the continuous variables, mean and standard deviations are listed, while percentages are listed for categorical variables.

\section{Data collection and data analysis}

The questionnaire was distributed to the science and mathematics teachers in selected Science, Technology, and Engineering (STE)-implementing schools during the academic year 2015-2016. Descriptive statistics, $t$ test for independent samples, and multiple linear regression analysis were employed in the analysis of data using the Statistical Package for Social Sciences (SPSS) version 13.0. Checking of assumptions was done before employing the parametric tests. Four regression models were constructed to examine the effects of inclusion of each WST model elements in the regression analysis: (I) the control model, adjusted for the background characteristics, namely, marital status, sex, age, and type of teacher; (II) the $W$ model, which is constructed using the control model and includes attitude toward ICT; (III) the WS model, which is constructed using the $W$ model and includes ICT skills index; (IV) the WST model, which is constructed using the WS model and includes the availability and use of ICT resources. The B and $\beta$ or the estimated regression coefficients of the unstandardized and standardized predictors, respectively, adjusted $R$-squared $\left(\Delta R^{2}\right)$, and change in $R$-squared $\left(\Delta R^{2}\right)$ were analyzed to determine separately the significance of each variable, and to determine the significance of the variables added to the model, considered jointly. Finally, the final regression models were constructed separately by science and mathematics teachers to see which significant variables they differ.

\section{Results}

To examine the significant differences in will, skill, tool, and integration variables between science and mathematics areas, independent samples t tests were conducted. $T$ test results revealed that there were significant differences in attitude toward ICT, ICT skills index, and ICT integration index (Table 2). Science teachers had significantly higher attitude toward ICT $(M=38.17, \mathrm{SD}=7.66)$ than mathematics teachers $(M=34.80, \mathrm{SD}=5.30 ; t(323)=4.62, p=0.00)$. The magnitude of the difference in the means of attitude index was moderate (eta squared =0.06). In terms of ICT skills, science teachers also scored significantly higher $(M=53.18, \mathrm{SD}=22.00)$ compared to mathematics teachers $(M=47.51, \mathrm{SD}=22.64 ; t(323)=2.29, p=0.02)$. The effect size of subject teaching area on ICT skills was small (eta squared $=0.02$ ). Moreover, higher integration index was found among science teachers $(M=67.07, \mathrm{SD}=17.57)$ than among mathematics teachers $(M=54.93, \mathrm{SD}=18.64 ; t(323)=6.04)$. The proportion of ICT integration index that can be explained by subject teaching area was moderate effect size (eta squared $=0.10$ ). There was no significant difference in the availability of ICT resources between science and mathematics teachers. 
Table 2 Results of $t$ test and descriptive statistics for attitude toward ICT (Will), ICT skills index (skill), availability of resources (tool) and ICT integration index by subject areas

\begin{tabular}{|c|c|c|c|c|c|c|c|c|c|}
\hline \multirow[t]{3}{*}{ Variables } & \multicolumn{3}{|c|}{$\begin{array}{l}\text { Descriptive Sta- } \\
\text { tistics }\end{array}$} & \multicolumn{6}{|c|}{$t$ test Results } \\
\hline & \multirow[t]{2}{*}{ Mean } & \multirow[t]{2}{*}{ SD } & \multirow[t]{2}{*}{$n$} & \multirow[t]{2}{*}{$t$} & \multirow[t]{2}{*}{ df } & \multirow[t]{2}{*}{$p$} & \multirow[t]{2}{*}{ Mean diff } & \multicolumn{2}{|c|}{$\begin{array}{l}95 \% \text { CI of the } \\
\text { mean difference }\end{array}$} \\
\hline & & & & & & & & Lower & Upper \\
\hline Attitude toward ICT & & & & 4.62 & 323 & 0.000 & 3.38 & 4.81 & 1.94 \\
\hline Science & 38.17 & 7.66 & 163 & & & & & & \\
\hline Mathematics & 34.80 & 5.30 & 162 & & & & & & \\
\hline ICT skills index & & & & 2.29 & 323 & 0.023 & 5.67 & 0.80 & 10.54 \\
\hline Science & 53.18 & 22.00 & 163 & & & & & & \\
\hline Mathematics & 47.51 & 22.64 & 162 & & & & & & \\
\hline Availability of ICT resources & & & & 0.78 & 323 & 0.435 & 0.19 & 0.67 & -0.29 \\
\hline Science & 5.19 & 2.14 & 163 & & & & & & \\
\hline Mathematics & 5.00 & 2.24 & 162 & & & & & & \\
\hline ICT integration index & & & & 6.04 & 323 & 0.000 & 12.14 & 8.19 & 16.09 \\
\hline Science & 67.07 & 17.57 & 163 & & & & & & \\
\hline Mathematics & 54.93 & 18.64 & 162 & & & & & & \\
\hline
\end{tabular}

Table 3 Regression coefficients of control variables on will and skill

\begin{tabular}{|c|c|c|c|c|c|c|c|c|}
\hline \multirow[t]{3}{*}{ Control variable } & \multicolumn{4}{|c|}{$\begin{array}{l}\text { Will } \\
\text { (adjusted } R \text { square }=0.06 \text { ) }\end{array}$} & \multicolumn{4}{|c|}{$\begin{array}{l}\text { Skill } \\
\text { (adjusted } R \text { square }=0.25 \text { ) }\end{array}$} \\
\hline & \multirow[t]{2}{*}{$B$} & \multirow[t]{2}{*}{$\beta$} & \multicolumn{2}{|c|}{$95 \%$ CI for $B$} & \multirow[t]{2}{*}{$B$} & \multirow[t]{2}{*}{$\beta$} & \multicolumn{2}{|c|}{$95 \%$ CI for $B$} \\
\hline & & & Lower & Upper & & & Lower & Upper \\
\hline Constant & $34.16^{* * *}$ & & 32.86 & 35.47 & $35.08 * * *$ & & 31.22 & 38.94 \\
\hline $\begin{array}{l}\text { Marital status ( } \text { single }=1 \text {; other- } \\
\quad \text { wise }=0 \text { ) }\end{array}$ & -0.92 & -0.06 & -2.63 & 0.79 & 4.83 & 0.10 & -0.23 & 9.89 \\
\hline Sex $($ male $=1) ;$ female $=0)$ & 1.32 & 0.09 & -0.38 & 3.01 & $6.87 * *$ & 0.13 & 1.85 & 11.88 \\
\hline $\begin{array}{l}\text { Age }(40 \& \text { below }=1 ; 41 \& \\
\text { above }=0)\end{array}$ & 1.04 & 0.08 & -0.47 & 2.55 & $18.80 * * *$ & 0.42 & 14.34 & 23.27 \\
\hline $\begin{array}{l}\text { Type of teacher }(\text { science }=1 ; \\
\text { mathematics }=0)\end{array}$ & $3.43 * * *$ & 0.25 & 1.99 & 4.87 & $5.20^{*}$ & 0.12 & 0.94 & 9.46 \\
\hline
\end{tabular}

$B$ beta, $\beta$ standardized beta, $C I$ for $B$ confidence interval for beta

$* p \leq 0.05, * * p \leq 0.01, * * * p \leq 0.001$

Table 3 shows the results of regression models of will and skill taking the control variables as predictors. On the will model, only type of teacher was found to be a significant predictor of the attitude toward ICT. Science teachers tend to have higher attitude toward ICT as compared to mathematics teachers. On the other hand, the skill model revealed that almost all control variables are significant predictors of ICT skills index, except marital status. The results suggest that high ICT skills 
index can be found more among male, single, and science teachers, compared to female, not single, mathematics teachers as comparison groups, respectively. Taking the control variables as predictors, the will model only explains 6 percent of the total variation of the attitude toward ICT while the skill model explains $25 \%$ of the total variation of the ICT skills index.

Table 4 presents the results of multiple linear regression models. In Model I, only the selected background characteristics of teachers, namely, marital status, sex, and age were included with the aim of controlling for their effects on subsequent,

Table 4 Regression coefficients of predictors on ICT integration index (general model)

\begin{tabular}{|c|c|c|c|c|c|}
\hline Predictor & $B$ & SE $B$ & $\beta$ & Adjusted $R^{2}$ & $\Delta R^{2}$ \\
\hline Model I & & & & $0.21 * * *$ & \\
\hline Constant & $47.57 * * *$ & 1.71 & & & \\
\hline Marital status ( single $=1$; otherwise $=0$ ) & $4.90 *$ & 2.24 & 0.12 & & \\
\hline Sex $($ male $=1 ;$ otherwise $=0)$ & $4.63 *$ & 2.22 & 0.11 & & \\
\hline Age $(40 \&$ below $=1 ; 41 \&$ above $=0)$ & $9.67 * * *$ & 1.98 & 0.25 & & \\
\hline Type of teacher $($ science $=1 ;$ mathematics $=0)$ & $11.91 * * *$ & 1.89 & 0.31 & & \\
\hline Model II & & & & $0.43 * * *$ & $0.22 * * *$ \\
\hline Constant & 0.65 & 4.43 & & & \\
\hline Marital status $($ single $=1$; otherwise $=0$ ) & $6.16^{* * *}$ & 1.91 & 0.15 & & \\
\hline Sex $($ male $=1 ;$ otherwise $=0)$ & 2.82 & 1.89 & 0.06 & & \\
\hline Age $(40 \&$ below $=1 ; 41 \&$ above $=0)$ & $8.24 * * *$ & 1.68 & 0.22 & & \\
\hline Type of teacher $($ science $=1 ;$ mathematics $=0)$ & $7.20 * * *$ & 1.66 & 0.19 & & \\
\hline Will & $1.37 * * *$ & 0.12 & 0.49 & & \\
\hline Model III & & & & $0.53 * * *$ & $0.10 * * *$ \\
\hline Constant & -0.57 & 4.04 & & & \\
\hline Marital status ( $\operatorname{single}=1$; otherwise $=0$ ) & $4.34 *$ & 1.75 & 0.10 & & \\
\hline Sex $($ male $=1 ;$ otherwise $=0)$ & 0.99 & 1.74 & 0.02 & & \\
\hline Age $(40 \&$ below $=1 ; 41 \&$ above $=0)$ & 2.50 & 1.69 & 0.07 & & \\
\hline Type of teacher $($ science $=1 ;$ mathematics $=0)$ & $6.53 * * *$ & 1.51 & 0.17 & & \\
\hline Will & $1.08 * * *$ & 0.12 & 0.38 & & \\
\hline Skill & $0.32 * * *$ & 0.04 & 0.38 & & \\
\hline Model IV & & & & 0.54 & $0.01 * * *$ \\
\hline Constant & -2.73 & 4.11 & & & \\
\hline Marital status ( single $=1$; otherwise $=0$ ) & $4.05 *$ & 1.74 & 0.10 & & \\
\hline $\operatorname{Sex}($ male $=1 ;$ otherwise $=0)$ & 1.52 & 1.74 & 0.04 & & \\
\hline Age $(40 \&$ below $=1 ; 41 \&$ above $=0)$ & 2.51 & 1.68 & 0.07 & & \\
\hline Type of teacher $($ science $=1 ;$ mathematics $=0)$ & $6.64 * * *$ & 1.50 & 0.17 & & \\
\hline Will & $1.05 * * *$ & 0.12 & 0.37 & & \\
\hline Skill & $0.30 * * *$ & 0.04 & 0.35 & & \\
\hline Tool & $0.83 *$ & 0.35 & 0.10 & & \\
\hline
\end{tabular}

$* p \leq 0.05, * * p \leq 0.01, * * * p \leq 0.001$

$B$ beta, $S E B$ standard error of beta, $\beta$ standardized beta 
more developed models. Results of Model I reveal significant effects of all the variables: marital status $(B=4.90, p \leq 0.001)$, sex $(B=4.63, p \leq 0.005)$; age $(B=9.67$, $p \leq 0.05)$; and type of teacher $(B=11.91, p \leq 0.001)$. This indicates that high ICT integration index can be found more among single, male, younger, science teachers than among married, female, older and mathematics teacher. Among the significant predictor variables, type of teacher has higher effects $(\beta=0.31)$ among the control variables. Selected background characteristics of teachers explained $21 \%$ of the total variability in ICT integration index.

Model II is the $W$ model, which includes attitude toward ICT aside from selected background characteristics of teachers. The inclusion of Will variable increased significantly the explained total variation in ICT integration index by $22 \%$. Model II explained $43 \%$ of the total variation in ICT integration index. Almost all variables are found to be significant predictors except sex: marital status $(B=6.16, p \leq 0.001)$, age $(B=8.24, p \leq 0.001)$; type of teacher $(B=7.20, p \leq 0.001)$; and will $(B=1.37$, $p=0.001$ ). Being married, younger, science teachers, and with high attitude (positive) toward ICT tend to have higher ICT integration index. Among the predictor variables, attitude toward ICT or will has the highest predictive value effect $(\beta=0.49)$.

In Model III (WS model), Skill element measured by the ICT skills index variable is added to the $W$ model. By adding the ICT skills index, the model now explained $53 \%$ of the total variation of ICT integration index, a significant increase of $10 \%$ from $43 \%$ in Model II. The significant predictors of ICT integration index are: marital status $(B=4.34, p \leq 0.05)$; type of teacher $(B=6.53, p \leq 0.001)$; will $(B=1.08$, $p \leq 0.001)$; and skill $(B=0.32, p \leq 0.001)$. This indicates that high ICT integration index is more likely among single, science, with high attitude toward ICT, and with high ICT skills index. Both will and skill variables have high significant predictor effects with the same coefficient value $(\beta=0.38)$ in this model.

Model IV (WST model) includes all elements of Will, Skill, and Tool along with selected background characteristics. With the inclusion of Tool element, the model explained more than half $(54 \%)$ of the total variation in ICT integration index. The significant predictors of ICT integration index in the final model are: marital status $(B=4.05, p \leq 0.05)$; type of teacher $(B=6.64, p \leq 0.001)$; will $(B=1.05, p \leq 0.001)$; skill $(B=0.30, p \leq 0.001)$; and tool $(B=0.83, p \leq 0.05)$. Results indicate that high ICT integration index can be found among single, science teachers, with high availability of ICT resources, with high ICT skills index, and with high (positive) attitude toward ICT. Among the significant predictors, attitude toward ICT has the highest standard regression coefficient $(\beta=0.37)$, followed by ICT skills index $(\beta=0.35)$.

When multiple regression was conducted separately for science and mathematics teachers the results of WST model were still significant (Table 5). However, differences between science and mathematics teaching areas occurred in terms of which among the factors the best predictor was. Among science teachers, age, will, skill, and tool were significant predictors of ICT integration. Attitude toward ICT or will was the best predictor $(\beta=0.41)$, followed by skill $(\beta=0.25)$ and then, tool $(\beta=22)$. The science model explained 52 percent of the variance of ICT integration index. On the other hand, only will and skill were found to be significant predictors of ICT integration among mathematics teachers. In mathematics model, ICT skills index 
Table 5 Separate regression coefficients of predictors on ICT integration index for science and mathematics teachers

\begin{tabular}{|c|c|c|c|c|c|c|c|c|}
\hline \multirow[t]{3}{*}{ Predictor } & \multicolumn{4}{|c|}{$\begin{array}{l}\text { Science } \\
\text { (adjusted } R \text { square }=0.52 \text { ) }\end{array}$} & \multicolumn{4}{|c|}{$\begin{array}{l}\text { Mathematics } \\
\text { (adjusted } R \text { square }=0.48 \text { ) }\end{array}$} \\
\hline & \multirow[t]{2}{*}{$B$} & \multirow[t]{2}{*}{$\beta$} & \multicolumn{2}{|c|}{$95 \% \mathrm{CI}$ for $\mathrm{B}$} & \multirow[t]{2}{*}{$B$} & \multirow[t]{2}{*}{$\beta$} & \multicolumn{2}{|c|}{$95 \%$ CI for $B$} \\
\hline & & & Lower & Upper & & & Lower & Upper \\
\hline Constant & -8.24 & & -22.34 & 5.87 & 2.87 & & -7.67 & 13.40 \\
\hline $\begin{array}{l}\text { Marital status ( } \text { single }=1 \text {; other- } \\
\quad \text { wise }=0 \text { ) }\end{array}$ & 3.89 & 0.10 & -0.54 & 8.31 & 4.96 & 0.12 & -0.32 & 10.24 \\
\hline Sex $($ male $=1 ;$ otherwise $=0)$ & 1.63 & 0.04 & -3.06 & 6.33 & 0.62 & 0.02 & -4.37 & 5.61 \\
\hline $\begin{array}{l}\text { Age }(40 \& \text { below }=1 ; 41 \& \\
\text { above }=0)\end{array}$ & $4.52 *$ & 0.13 & 0.21 & 8.82 & -0.19 & -0.01 & -5.31 & 4.93 \\
\hline Will & $1.35^{* *}$ & 0.41 & 0.96 & 1.75 & $0.95 * * *$ & 0.39 & 0.66 & 1.24 \\
\hline Skill & $0.20 * *$ & 0.25 & 0.09 & 0.31 & $0.37 * * *$ & 0.45 & 0.25 & 0.49 \\
\hline Tool & $1.76^{* *}$ & 0.22 & 0.80 & 2.72 & -0.02 & -0.00 & -1.02 & 0.99 \\
\hline
\end{tabular}

$* p \leq 0.05, * * p \leq 0.01, * * * p \leq 0.001$

$(\beta=0.45)$ was the best predictor, followed by the attitude toward ICT $(\beta=0.39)$. The R square of mathematics model (0.48) was a bit lower than that of the science model. In contrast with bivariate analyses using t tests, the multivariate analyses reveal no significant differences in skill and will between science and mathematics teachers by examining the $95 \%$ confidence interval for B of each model since the values intersect at certain points (i.e., Skill: Science $=0.09$ Lower, 0.31 Upper vs. Mathematics $=0.25$ Lower, 0.49 Upper; Will=0.96 Lower, 1.75 Upper vs. Mathematics $=0.66$ Lower, 1.24 Upper).

\section{Summary and conclusion}

This current study aimed to examine significant differences in the will, skill, tool, and ICT integration in teaching between science and mathematics teaching areas. First, the results of the study confirmed past studies that will, skill, and tool did predict the integration of ICT in teaching science and mathematics, both when taken together and as separate subject areas, in the Philippine context. The results of regression analyses indicated that the WST model holds true for these teachers and explained up to $54 \%$ of the variances of their ICT integration. Second, bivariate analysis and preliminary regression models revealed that science teachers in this study had higher values in all indices of will, skill, tool, and ICT integration in teaching than mathematics teachers. Thus, compared to mathematics teachers, they had significantly higher positive attitude toward ICT and higher ICT skills; they also reported more available ICT resources; and they integrated ICT more often in teaching the subject area. However, separate final regression models did not show significant difference in the will, skill, and tool between science and mathematics teachers. Third, the study revealed that the WST model of ICT integration in teaching differs 
between science and mathematics areas, specifically in terms of which among the factors had the strongest influence on ICT integration. In the science teaching area, attitude toward ICT has the strongest influence on ICT integration, followed by ICT skills and then, availability of ICT resources. In the mathematics teaching area, on the other hand, the skill was the best predictor, followed by attitude toward ICT. Tool was not found to be a significant predictor in the mathematics teaching area.

\section{Discussion and recommendation}

The present study was able to validate the WST model in predicting and explaining ICT integration in teaching science and mathematics in the Philippines. However, it found a different proportion of variance explained by the model as compared to other studies. The comprehensive study of Morales (2006) found greater proportions and showed that the WST model explained up to $90 \%$ of variation in the level of ICT integration for both Mexican and US elementary and middle school teachers. The proportion explained by the current study was closer to that of Farjon et al. (2019) that found an average proportion, indicating that the WST model explained $60 \%$ of the level of ICT integration among pre-service teachers in Dutch teacher education. The almost similar proportion may be explained in the similar method of regression analysis used. In addition, the study of Agyei and Voogt (2010) among prospective and practicing mathematics teachers in Ghana found smaller proportions and showed that the WST explained up to $43 \%$ of the variation in ICT integration. Nevertheless, the WST model seemed to be a credible method in predicting and explaining the ICT integration of teachers, to a greater or lesser extent, regardless of subject teaching area, level or type of teaching, and geographical background. Moreover, despite of not using the conventional measures of will, skill, tool, and integration constructs, the present study yielded high internal consistency and significant results. Thus, the use of multiple items in measuring ICT integration in teaching can be a good alternative to the conventional use of one-indicator construct (i.e., Stages of Adoption, Concerns-based Adoption Model, or Apple Classroom of Tomorrow Stages of Technology).

While past studies on WST model (e.g., Agyei and Voogt 2010; Farjon et al. 2019; Knezek et al.; Morales, 2006) focused on general effects of will, skill, and tool on ICT integration into teaching of a single subject area or general teaching level, this study provided differential analysis of these predictors between two subject teaching areas (i.e., science and mathematics). As suggested by Nelson et al. (2019), technology and content-area faculty should work hand in hand for more effective ICT-integrated teaching and learning process. This analysis by subject teaching area, therefore, is instructive in understanding successful integration of ICT into teaching, which is contextually situated by subject area (Foulger et al. 2015). This present study confirmed past studies (Howard and Maton 2011; Jang and Tsai 2012; Sezer 2015) that mathematics teachers were less likely to integrate ICTs in classrooms. On the other hand, same with the study of Jang and Tsai (2012) the present study also found that science teachers had higher ICT skills and integration than mathematics teachers. 
Moreover, the difference in which among the factors has the highest significant effect on ICT integration is also notable-will for science teachers while skill for mathematics teachers. This suggests distinct approach in providing capacity training development for teachers by subject teaching area. Among science teachers, the importance of ICT integration in teaching should be highlighted first to increase their level of attitude toward ICT prior to skills development. On the other hand, ICT knowledge and skills should be a primary focus in providing teacher training programs for mathematics teachers who may have technical requirement to facilitate integration of ICT in teaching the subject.

The attitude of teachers toward ICT can be greatly improved prior to skills development by understanding their individual perception of how ICT can help improve student learning, as well as the reasons that hinder them from using it in their class. Based on these perceptions, the school administration can provide the enabling environment to motivate teachers to explore ICT by making ICT resources and technical support accessible to them so they can have practical knowledge and experience in using ICT even outside of actual teaching pedagogy. Peer group learning and mentoring may also be encouraged if there are teachers who are way advanced in terms of ICT skills. Schools should encourage groups of teachers to come out with their own concepts of how science and mathematics lessons can be improved by integrating ICT, and then scale up their ideas as projects or modules. Teachers may also be exposed to other teachers (within the same school or in other schools) by observing how they use ICT in their science and mathematics classes and interact with them to better understand how such practice can improve student performance. These actual exposures can provide them with options on how to construct their lessons and enable students to build on it to improve their learning and achieve the intended outcomes even prior to skills development.

Interestingly, tool or availability of ICT resources has the lowest predictive value in the WST model of ICT integration among science teachers and not even a significant predictor among mathematics teachers. This finding suggests that ICT tool may be necessary, but it is not the main condition to integrate ICT into teaching. With the ubiquitous presence of ICT resources nowadays, teachers can make the initiative to avail of ICT resources other than the school can offer for them if they have the will and the skill.

\section{Limitation of the study}

This study only sampled three to four schools from selected provinces in the major islands of the Philippines. It also used purposive, non-probability sampling in the selection of respondents and schools. Thus, making generalizations from the findings of this study should be made with caution. With the limited number of respondents and schools sampled and the type of sampling used, there is no assumption of representativeness of sampled data to the general population. 


\section{Implications}

The findings of the study point to the importance of the internal and external factors to the integration of ICT in science and mathematics (S\&M) teaching. It underpins the value of considering complex models to describe, explain, and predict the adoption and implementation of ICT-based teaching in schools. Despite its limitations due to its small sample size, the study provides the momentum for future research in the country that will contribute to the body of literature which examines the interplay of teacher variables predicting ICT integration in the classroom. A closer look into the actual description of ICT integration by teachers who were the respondents of the study can reveal the degree by which ICT is used to teach S\&M subjects, and the challenges that must be surmounted in doing so.

The results are also useful in developing policies that will address the barriers that negatively influence the use of ICT in teaching practices for both S\&M and non-S\&M teachers. Knowing that teachers' ICT competence and attitude toward ICT are both important predictive factors, pre-service and in-service education of teachers may also be assessed to determine if they are adequately addressing these factors. This can lead to the formulation of more responsive curriculum at the preservice level by the Commission on Higher Education (CHED) and Teacher Education Institutions (TEIs) and continuing professional development programs by the Department of Education (DepEd) that are able to provide the competence and confidence among teachers to use ICT in their practice. Moreover, the policies to computerize based on the Department Order (DO) 78, series 2010 (Department of Education [DepEd] 2010) and to provide Internet connectivity to public schools based on the DO 46, series 2011 (DepEd 2011) should be evaluated and matched with teachers' competencies and capabilities so that both skills and tools are maximized.

Open Access This article is licensed under a Creative Commons Attribution 4.0 International License, which permits use, sharing, adaptation, distribution and reproduction in any medium or format, as long as you give appropriate credit to the original author(s) and the source, provide a link to the Creative Commons licence, and indicate if changes were made. The images or other third party material in this article are included in the article's Creative Commons licence, unless indicated otherwise in a credit line to the material. If material is not included in the article's Creative Commons licence and your intended use is not permitted by statutory regulation or exceeds the permitted use, you will need to obtain permission directly from the copyright holder. To view a copy of this licence, visit http://creativecommons.org/licen ses/by/4.0/.

\section{Appendix: Survey questionnaire for teachers}

See Appendix Table 6. 
Table 6 Pearson product-moment correlation matrix of variables

\begin{tabular}{lcllllll}
\hline & Sex & Age & Type of teacher & Tool & Will & Skill & $\begin{array}{l}\text { ICT } \\
\text { Integration } \\
\text { Index }\end{array}$ \\
\hline Sex & & & & & & & \\
Age & 1.000 & & & & & & \\
Type of teacher & 0.097 & 1.000 & & & & & \\
Tool & -0.065 & 0.040 & 1.000 & & & & \\
Will & -0.048 & $0.147^{* *}$ & 0.043 & 1.000 & & & \\
Skill & 0.062 & 0.077 & $0.249^{* *}$ & $0.181^{* *}$ & 1.00 & & \\
ICT integration index & $0.189^{* *}$ & $0.466^{* *}$ & $0.126^{*}$ & $0.314^{* *}$ & $0.324^{* *}$ & 1.000 & \\
\hline
\end{tabular}

\section{References}

Agyei, D. D., \& Voogt, J. M. (2010). Exploring the potential of the will, skill, tool model in Ghana: Predicting prospective and practicing teachers' use of technology. Computers \& Education, 56(1), 91-100.

Aramide, K. A., Lapido, S. O., \& Adebayo, I. (2015). Demographic variables and ICT access as predictors of information communication technologies' usage among science teachers in Federal Unity Schools in Nigeria. Library Philosophy and Practice; Lincoln: 1-27.

Buabeng-Andoh, C. (2012). Factors influencing teachers' adoption and integration of information and communication technology into teaching: A review of the literature. International Journal of Education and Development using Information and Communication Technology (IJEDICT), $8(1), 136-155$.

Christensen, R., \& Knezek, G. (2001). Profiling teacher stages of adoption for technology integration. Computers in New Zealand Schools, 13(3), 25-29.

Christensen, R., \& Knezek, G. (2008). Self-report measures and findings for information technology attitudes and competencies. In J. Voogt \& G. Knezek (Eds.), International handbook of information technology in primary and secondary education (pp. 349-366). New York: Springer.

Department of Education (2010, June 10). Guidelines on the implementation of the DepEd computerization program (DCP). Retrieved October 23, 2018, from http://www.deped.gov.ph/2010/06/10/ do-78-s-2010-guidelines-on-the-implementation-of-the-deped-computerization-program-dcp/.

Department of Education. (2011, June 11). Revised guidelines on the implementation of the DepEd internet connectivity project (DICP). Retrieved October 23, 2018, from http://www.deped.gov. $\mathrm{ph} / 2011 / 06 / 01 / \mathrm{do}-46-\mathrm{s}-2011$-revised-guidelines-on-the-implementation-of-the-deped-internetconnectivity-project-dicp/.

Department of Education and Training Evaluation and Accountability Western Australia. (2006). Teacher ICT skills evaluation of the Information and Communication Technology (ICT) levels of Western Australian Government school teachers. Retrieved from http://www.det.wa.edu.au/ accountability/detcms/education/evaluation-and-accountability/binary-files/evaluation-reports/ teacher-ict-skills-2006.en?cat-id=13027342.

Farjon, D., Smits, A., \& Voogt, J. (2019). Technology integration of pre-service teachers explained by attitudes and beliefs, competency, access, and experience. Computers \& Education., 130(2019), 81-93.

Foulger, T. S., Buss, R. R., Wetzel, K., \& Lindsey, L. (2015). Instructors' growth in TPACK: Teaching technology-infused methods courses to preservice teachers. Journal of Digital Learning in Teacher Education, 31(4), 134-147. https://doi.org/10.1080/21532974.2015.1055010

Gebhardt, E., Thomson, S., Ainley, J., \& Hillman, K. (2019). Gender differences in computer and information literacy: An in-depth analysis of data from ICILS. Boston: Springer.

Gil-Flores, J., Rodriguez-Santero, J., \& Torres-Gordillo, J. (2017). Factors that explain the use of ICT in secondary-education classrooms: The role of teacher characteristics and school infrastructure. Computers in Human Behavior, 68, 441-449. https://doi.org/10.1016/j.chb.2016.11.057 
Hew, K. F., \& Tan, C. Y. (2016). Predictors of information technology integration in secondary schools: Evidence from a large scale study of more than 30,000 students. PLOS ONE. https://doi. org/10.1371/journal.pone.0168547

Howard, S., \& Maton, K. (2011). Theorising knowledge practices: A missing piece of the educational technology puzzle. Research in Learning Technology, 19(3), 191-206. https://doi.org/10.3402/ rlt.v19i3.17109

Ifinedo, E., Rikala, J., \& Hamalainen, T. (2020). Factors affecting Nigerian teacher educators' technology integration: Considering characteristics, knowledge constructs, ICT practices and beliefs. Computers \& Education, 146, 1-17. https://doi.org/10.1016/j.compedu.2019.103760

Inan, F. A., \& Lowther, D. L. (2010). Factors affecting technology integration in K-12 classrooms: A path model. Educational Technology Research and Development, 58, 137-154. https://doi. org/10.1007/s11423-009-9132-y

Jang, S. J., \& Tsai, M.-F. (2012). Exploring the TPACK of Taiwanese elementary mathematics and science teachers with respect to use of interactive whiteboards. Computers \& Education, 59(2), 327-338. https://doi.org/10.1016/j.compedu.2012.02.003

Knezek, G., Christensen, R., \& Fluke, R. (2003). Testing a will, skill, tool model of technology integration. In Paper presented to the Annual Meeting of the American Educational Research Association (AERA). Chicago. IL.

Knezek, G., \& Christensen, R. (2016). Extending the will, skill, tool model of technology integration: Adding pedagogy as a new model construct. Journal of Computing in Higher Education, 28, 307-325.

Lau, B.T., \& Sim, C.H. (2008). Exploring the extent of ICT adoption among secondary school teachers in Malaysia. International Journal of Computing and ICT Research, 2(2), 19-36. Retrieved from http:// citeseerx.ist.psu.edu/viewdoc/download?doi=10.1.1.372.7344\&rep=rep1\&type=-pdf\#page=19.

Maton, K. (2010). Progress and conons in the arts and humanities: Knowers and gazes. In K. Maton \& R. Moore (Eds.), Social realism, knowledge and the sociology of education (pp. 154-178). London: Continuum.

Mishra, P., \& Koehler, M. J. (2006). Technological pedagogical content knowledge: A new framework for teacher knowledge. Teachers College Record., 108(6), 1017-1054.

Morales, C. (2006). Cross-cultural validation of the will, skill, tool model of technology integration. Unpublished doctoral dissertation, University of North Texas, Denton, TX.

Morales, C., Knezek, G., Christensen, R., \& Avila, P. (Eds.). (2005). The will, skill, tool model of technology integration. A conceptual approach to teaching and learning with technology. Mexico: ICLE.

Nelson, M. J., Voithofer, R., \& Cheng, S.-L. (2019). Mediating factors that influence the technology integration of teacher educators. Computers \& Education, 128(2019), 330-344. https://doi. org/10.1016/j.compedu.2018.09.023

O'Bannon, B. W., \& Thomas, K. (2014). Teacher perceptions of using mobile phones in the classroom: Age matters! Computers \& Education, 74, 15-25. https://doi.org/10.1016/j.compedu.-2014.01.006

Oosterwegel, A., Littleton, K., \& Light, P. (2004). Understanding computer-related attitudes through an idiographic analysis of gender- and self-representations. Learning and Instruction, 14(2), 215-233. https://doi.org/10.1016/S0959-4752(03)00093-8

Peeraer, J., \& Van Petegem, P. (2010). Factors influencing integration of ICT in higher education in Vietnam. In: Z. Abas, I. Jung \& J. Luca (Eds.), Proceedings of Global Learn 2010 (pp. 916-924). Waynesville: Association for the Advancement of Computing in Education (AACE).

Petko, D. (2012). Teachers' pedagogical beliefs and their use of digital media in classrooms: Sharpening the focus of the 'will, skill, tool' model and integrating teachers' constructivist orientations. Computers \& Education, 58(4), 1351-1359.

Sezer, B. (2015). Examining technopedagogical knowledge competencies of teachers in terms of some variables. Procedia-Social and Behavioral Sciences, 174, 208-215. https://doi.org/10.1016/j.sbspr o.2015.01.648

Shaw, H., Ellis, D. A., \& Ziegler, F. V. (2018). The Technology Integration Model (TIM). Predicting the continued use of technology. Computers in Human Behavior, 83, 204-214. https://doi.org/10.1016/j. chb.2018.02.001

Sink, C., Sink, M., Stob, J., \& Taniguchi, K. (2009). Further evidence of gender differences in high school-level computer literacy. Chance, 21, 49-53. https://doi.org/10.1007/s00144-008-0011-9

Scherer, R., Siddiq, F., \& Teo, T. (2015). Becoming more specific: Measuring and modeling teachers' perceived usefulness of ICT in the context of teaching and learning. Computers \& Education, 88, 202-214. https://doi.org/10.1016/j.compedu.2015.05.005 
Siddiq, F., Scherer, R., \& Tondeur, J. (2016). Teachers' emphasis on developing students' digital information and communication skills (TEDDICS): A new construct in $21^{\text {st }}$ century education. Computers \& Education, 92-93, 1-14. https://doi.org/10.1016/j.compedu.2015.10.006

Taimalu, M., \& Luik, P. (2019). The impact of beliefs and knowledge on the integration of technology among teacher educators: A path analysis. Teaching and Teacher Education, 79, 101-110. https:// doi.org/10.1016/j.tate.2018.12.012

Teo, T., \& Bahçekapili, E. (2012). An assessment of pre-service teachers' technology acceptance in Turkey: A structural equation modeling approach. The Asia-Pacific Education Researcher, 21(1), 191-202.

Tondeur, M., Valcke, M., \& van Braak, J. (2008). A multidimensional approach to determinants of computer use in primary education: teacher and school characteristics. Journal of Computer Assisted Learning, 24, 494-506. https://doi.org/10.1111/j.1365-2729.2008.00285.x

Vannatta, R. A., \& Fordham, N. (2004). Teacher dispositions as predictors of classroom technology use. Journal of Research on Technology in Education, 36(4), 253-271.

Volman, M., \& van Eck, E. (2001). Gender equity and information technology in education: The second decade. Review of Educational Research, 71, 613-634. https://doi.org/10.3102/2F0034654307100 4613

Vongkulluksn, V. W., Xie, K., \& Bowman, M. A. (2018). The role of value on teachers' internalization of external barriers and externalization of personal beliefs for classroom technology integration. Computers \& Education, 118, 70-81. https://doi.org/10.1016/j.compedu.2017.11.009

Voogt, J., \& Knezek, G. (Eds.). (2008). International handbook of information technology in primary and secondary education. Berlin: Springer.

Zubkovic, B. R., Pahljina-Reinic, R., \& Kolic-Vehovec, S. (2017). Predictors of ICT use in teaching in different educational domains. European Journal of Social Sciences Education and Research, 11(2), 145-154. Retrieved from http://journals.euser.org/files/articles/ejser_-sep_dec_17_nr_2/Barba ra.pdf.

Publisher's Note Springer Nature remains neutral with regard to jurisdictional claims in published maps and institutional affiliations.

Mr. Randolf S. Sasota is a Senior Science Research Specialist at the Department of Science and Technology - Science Education Institute. Concurrently, he also teaches at the University of the Philippines - Diliman College of Education as Senior Lecturer. He teaches Statistical Methods applied to Education, Psychometric Theory, and Statistics in Test and Scale Development. He specializes in quantitative data analysis using SPSS and R programming.

Dr. Ruby R. Cristobal heads the S\&T Manpower Education Research and Promotions Division (STMERPD) of the Science Education Institute (SEI), the S\&T human resources development arm of the Department of Science and Technology (DOST) of the Government of the Philippines. As Chief Science Research Specialist, she leads the various units which undertake science education research and studies on human resource in science and technology, science culture promotion, and information systems and IT infrastructure development works in the Institute. She specializes in science communication research and advocacy and has extensive work in the development and production of educational media programs. She hosts a weekly science radio program, and serves as a science news correspondent/volunteer to a number of news programs here and abroad.

Ms. Imelda S. Sario is a science researcher for more than 30 years at the Department of Science and Technology. Currently, she conducts policy research studies relating to S\&T human resources, including Tracer studies of DOST-SEI scholar-graduates. Ms. Sario serves as the Unit Head of the Research Unit of the Science Education Institute, Science and Technology Manpower Education Research and Promotion Division. She received her MS degree in Public Health-Nutrition from the University of the Philippines, Manila and obtained a diploma in Community Health and Nutrition in Wageningen, The Netherlands. 
Dr. Josette T. Biyo obtained her BS Biological Sciences from the University of the Philippines Visayas and received her Master's and PhD degrees both in Biology from De La Salle University, Manila. Dr. Biyo is an educator with more than 25 years of teaching experience. She then became the Director of the Philippine Science High School Western Visayas Campus (PSHS-WVC), and eventually, the Executive Director of the PSHS System. Currently, she is the Director of the Department of Science and Technology- Science Education Institute (DOST-SEI).

Dr. Joselito C. Magadia is a Professor at the School of Statistics, University of the PhilippinesDiliman. Currently, he serves as Assistant Director for Test Development and Research at the Office of Admissions of the UP System. He previously served as Director of the Graduate Studies Program of the School of Statistics and as Investment Officer of the UP System. He also served as Editor-in-Chief of The Philippine Statistician. 